\title{
Introdução à obra de Jon Maitrejean
}

\author{
Fernando Guillermo Vázquez Ramos, \\ Miguel Antonio Buzzar, Paulo Yassuhide Fujioka*
}

Resumo A figura de Jon Andoni Vergareche Maitrejean (1929), que estudou na FAU-USP, graduando-se em 1954, permanece fora do âmbito das publicações especializadas, pois pouco tem se escrito e pesquisado sobre sua extensa e importante obra, especialmente aquela vinculada à atividade industrial. Este artigo se debruça de forma panorâmica sobre a vida e a obra do arquiteto desde a época em que começou sua atividade docente na FAU-USP, marcada por momentos terríveis, como o afastado compulsório em 1968, uma prática contínua que se desenvolve até hoje, ministrando a disciplina de projeto. Trata-se de um arquiteto com uma longa vida profissional também, pois projeta desde os anos 1950. Engajou-se primeiro no IAB e também no SASP, do qual foi presidente (1978-1980).

Palavras-chave: Arquitetura Moderna Paulista, industrialização da construção, arquitetura varejista.

\section{Author of the project Arq. Jon Maitrejean}

\begin{abstract}
The figure of Jon Andoni Vergareche Maitrejean (1929), who studied at FAU-USP, graduating in 1954, remains outside the scope of the specialized publications, because little has been written and researched on its extensive and important work, especially the oeuvres which were linked to industrial activity. This article, in a panoramic way, focuses on life and the architect's work from the time he began his teaching activity at FAU-USP, marked by terrible moments, such as compulsory retirement in 1968, and his ongoing practice that develops today at classes of architectural design. It is an architect with a long professional life, which designs since the 1950s. He first involved in the IAB and also in the SASP, of which was president (1978-1980).
\end{abstract}

Key words: São Paulo's Modern Architecture, industrialization of construction, retail architecture.

\section{Autor del proyecto Arq. Jon Maitrejean}

Resumen La figura de Jon Andoni Vergareche Maitrejean (1929), que estudió en la FAU-USP, graduándose en 1954, permanece fuera del ámbito de las publicaciones especializadas, poco se ha escrito e investigado sobre su obra, especialmente aquella vinculada a la actividad industrial. Este artículo se centra sobre la vida y la obra del arquitecto desde la época en que comenzó su actividad docente en la FAU-USP, jalonada de momentos terribles, como el alejamiento obligatorio en 1968, una práctica continua que se desarrolla hasta hoy, ministrando la disciplina de proyecto. Se trata de un arquitecto con una larga vida profesional, pues proyecta desde los años 1950. Se comprometió primero en el IAB y también en el SASP, del cual fue presidente (1978-1980).

Palavras clave: Arquitectura Moderna Paulista, industrialización de la construcción, arquitectura comercial. 
* Fernando Guillermo Vázquez Ramos é Arquiteto e Urbanista, professor do Programa de PósGraduação em Arquitetura e Urbanismo da Universidade São Judas Tadeu, ORCID: <https:// orcid.org/0000-0003-34725598>; Miguel Antonio Buzzar é Arquiteto e Urbanista, professor do Instituto de Arquitetura e Urbanismo da Universidade de São Paulo, ORCID: <https://orcid. org/0000-0001-6251-0338>; Paulo Yassuhide Fujioka é Arquiteto e Urbanista, professor do Instituto de Arquitetura e Urbanismo da Universidade de São Paulo, ORCID: <https://orcid. org/0000-0003-2113-6778>.

\footnotetext{
1 Neto de bascos, mas filho de brasileiro, pois seu pai tinha nascido no Brasil, em Uruguaiana, onde seu avô fizera fortuna montando uma empresa de exportação de madeira. Os negócios foram muito bem e seu pai voltou ao País Basco onde nasceu Jon em 1929, em Eibar, uma pequena comunidade entre Bilbao e San Sebastian. Contudo, por envolvimentos políticos durante a guerra civil espanhola, do lado republicano, a família emigrou para o Brasil. Primeiro o pai, em 1939, fugindo pela França, e depois Jon e sua mãe, que com passaporte brasileiro, chegaram ao Brasil em 1941. Informação verbal recolhida na entrevista realizada no dia 3 de agosto de 2018 pelos professores Fernando G. Vázquez Ramos, Miguel Antonio Buzzar e Paulo Y. Fujioka.
}

on Andoni Vergareche Maitrejean (1929) ${ }^{1}$ faz parte do que pode-se chamar de $1^{\text {a }}$ geração de arquitetos modernos formados na modernidade. São aqueles profissionais que nascidos entre 1925 e 1935, e em alguns casos até o inicio da 2a Guerra Mundial, que se formaram em escolas que de alguma forma se encontravam, direta ou indiretamente, sob o ministério tanto da $1^{\text {a }}$ geração de arquitetos modernos brasileiros, como daqueles que se estabeleceram no Brasil, e que atuavam em São Paulo, ou também em São Paulo, como: Abelardo Riedy de Souza (1908, RJ), Adolph Franz Hepe (1902, Al.), Alvaro Bital Brasil (1909, SP), Bernard Rudofsky (1905, R.Chq.), Carlos Cascaldi (1918, SP), Eduardo Augusto Kneese de Mello (1906, SP), Giancarlo Palanti (1906, It.), Hélio de Queiroz Duarte (1906, RJ), Henrique Ephim Mindlin (1911, SP), Ícaro de Castro Mello (1913, SP), Jacques Émile Paul Pilon (1905, Fr.), João Batista Vilanova Artigas (1914, PR), Lina Bo Bardi (1914, It.), Marcelo Roberto (1908, RJ), Oscar Niemeyer (1907, RJ), Oswaldo Arthur Bratke (1907, SP), Rino Levi (1901, SP) e Zenon Lotufo (1911, SP), dentre outros. Estes arquitetos, que tinham entre 40 e 50 anos, nos anos 1950, estavam em pleno desenvolvimento de suas carreiras e foram importantes referências (eles próprios e suas obras) para os jovens estudantes que se formaram no início dos anos 1950.

Muitos desses jovens, que se formaram nesse momento, estudaram com professores que integram a lista acima mencionada, como: Abelardo de Souza, João Vilanova Artigas ou Zenon Lotufo. Estudaram ainda, dentro do campo de referências da arquitetura moderna, fosse quem buscasse estabelecer interlocução com a obra de a Frank Lloyd Wright ou a de Le Corbusier, ou ainda admirasse arquitetos locais como Niemeyer ou os irmãos Roberto. Ainda que não estudassem em edifícios modernos, pois nem a FAU-USP nem o Mackenzie tinham essas acomodações, os da FAU-USP, pelo menos, tiveram a oportunidade de trabalhar no Ateliê, o anexo de estrutura e cobertura metálica construído nos fundos da Vila Penteado, na Rua Maranhão. Essa experiência espacial e construtiva, de convívio e de troca de conhecimentos e de dúvidas, nesse singelo prédio também alimentou a formação moderna dos jovens estudantes, como demonstra sua produção posterior. Maitrejean fazia parte assim de um grupo de jovens promissores, que começaram sua atividade profissional entre 1950 e 1960 aproximadamente, dentre os quais destacam-se: Carlos Lemos (1925, Mackenzie 1950), Carlos Millan (1927 - Mackenzie, 1951), Eduardo de Almeida (1933 - FAU-USP, 1960), Fábio Penteado (1929 - Mackenzie, 1953), Joaquim Guedes (1932 - FAU-USP, 1954), João Toscano (1933 - FAU-USP, 1957), Jorge Wilheim (1928 - Mackenzie, 1952), Julio Katinsky (1932 - FAU-USP, 1957), Ludovico Martino (1933 - FAU-USP, 1960), Paulo Mendes da Rocha (1928 - Mackenzie, 1954), Pedro Paulo de Melo Saraiva (1933 - Mackenzie, 1955), Roger Zmekhol (1928 - FAU-USP, 1952), Rosa Kliass (1932 - FAU-USP, 1955) e Siegbert Zanettini (1934 - FAU-USP, 1961).

Essa geração não teve que dar o salto entre a arquitetura tradicional e a moderna, atuou desde os primeiros projetos já nas fileiras do modernismo, tanto porque sua formação acadêmica foi fundamentada nas premissas da arquitetura moderna, ainda 
Figura 1: Carimbo utilizado pelo Arquiteto nos últimos projetos. Fonte: Fotografia de Fernando Vazquez.

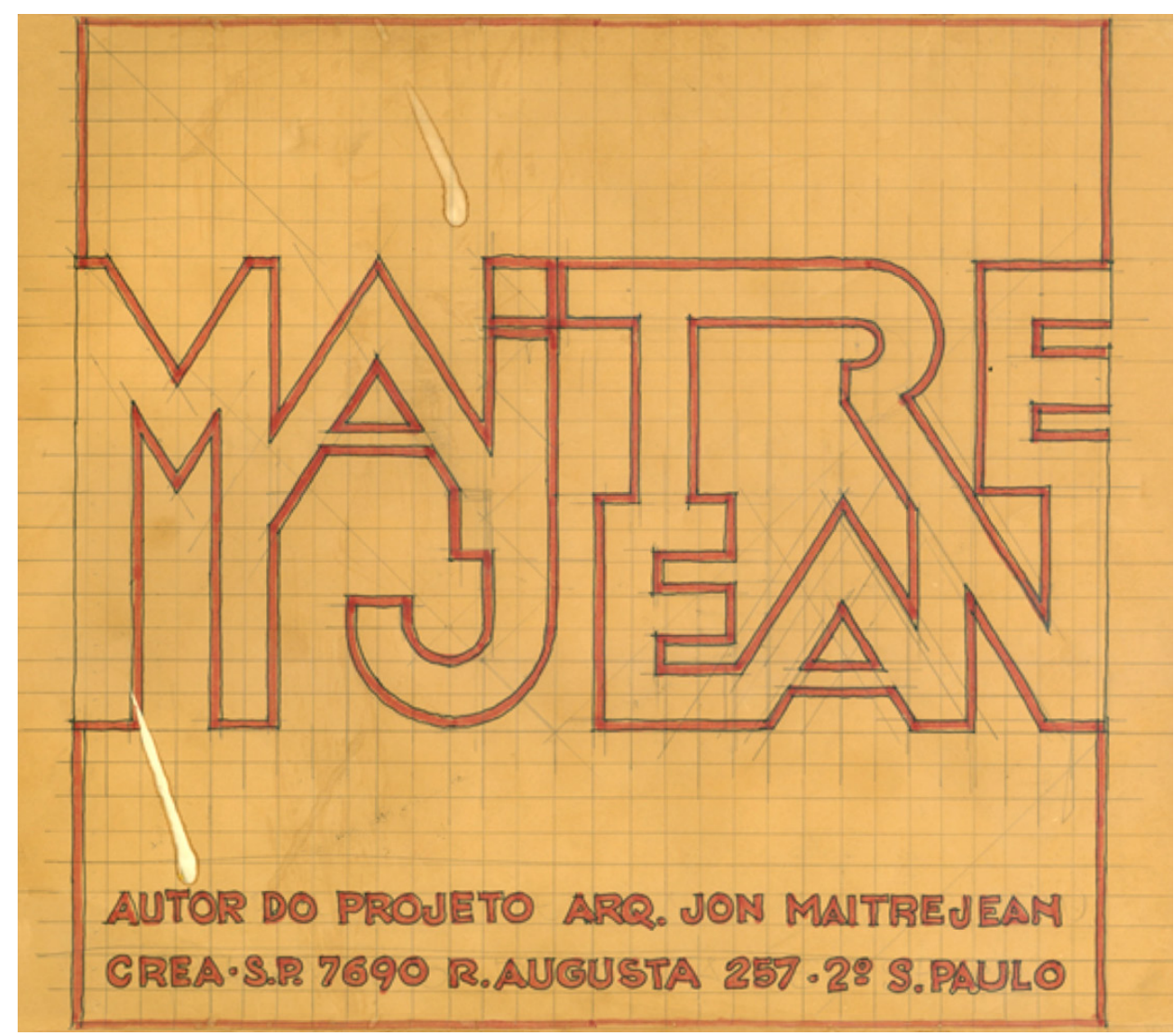

que a estrutura curricular fosse em grande parte conservadora, ou porque trabalharam junto a arquitetos modernos em seus escritórios, inicialmente como desenhistas para depois exercerem atividades de arquitetos plenos. Muitos deles, ainda se ligaram desde jovens, ainda estudantes, às atividades profissionais do Instituto dos Arquitetos do Brasil, Departamento São Paulo (IAB-SP), com o que desde cedo estiveram lidando com questões de ofício e de definição da profissão do arquiteto em um Brasil que ainda precisava definir a atribuição desse profissional. Lutaram assim desde cedo pela profissão e se constituíram como arquitetos e como professores, passando aos jovens que estudaram posteriormente com eles, nos anos 1960, a força moral, a ética de projeto, e o interesse nas questões construtivas e da industrialização, que foram, e talvez continuem sendo ainda, determinantes para a compreensão do fenômeno, bastante unitário, apesar das diferenças formais, que representa a arquitetura moderna paulista, no momento de sua consolidação, nos anos 1960 e 1970.

Os caminhos que esses arquitetos tomaram após o divisor de águas do golpe de 1964, e especialmente, após a ruptura das garantias individuais dos atos de 1969, que mudou a vida de muitos deles, especialmente a de Maitrejean, dependeu muito das oportunidades que tiveram para poder desenvolver suas respectivas sensibilidades pessoais. A marca da modernidade, contudo, nunca foi delével e os acompanhou pela vida toda. 
2 Anhaia Mello, além de primeiro Diretor da FAU-USP, foi: Vereador na década de 1920; Prefeito de São Paulo entre 06/12/1930 e 25/07/1931 e 14/11/1931 e 04/12/1931; diretor do Centro de Pesquisas e Estudos Urbanísticos (CPEU) da FAUUSP, instalado em 1955, entre 1957 e 1961, dentre outras funções e cargos exercidos.
3 Em 1954 houve um concurso de títulos para preencher a regência de "Composição de Arquitetura, Pequenas Composições I e II" e "Composição de Arquitetura, Grandes Composições I, II e III", Artigas que era o professor que ministrava essas disciplinas perdeu o concurso, quem ganhou foi Abelardo de Souza, que era seu assistente. (RIBEIRO; RIBEIRO; ROSENDO, 2001, p.186)

\section{Formação do arquiteto e professor}

Jon Maitrejean ingressou em 1949, como primeiro colocado, na segunda turma da Faculdade de Arquitetura e Urbanismo da Universidade de São Paulo, fundada em 1948 por Luis Ignácio de Anhaia Mello, ${ }^{2}$ seu diretor até 1951. Nesses primeiros anos de funcionamento da FAU-USP, a grade curricular era uma mistura entre disciplinas técnicas, oriundas da Escola Politécnica, e artísticas, ministradas por artistas plásticos. Engenheiros-arquitetos, como João Batista Vilanova Artigas, faziam parte também desse variado conglomerado de profissionais, voltados não somente para a arquitetura, como para o urbanismo, ainda que as disciplinas deste campo se encontrassem concentradas nos últimos anos de formação. Anhaia Mello foi o responsável pela inclusão das matérias de urbanismo, pois além de lecionar estética e composição, praticava e ministrava essa disciplina. A estrutura de ensino da flamante nova escola era, no entanto, um modelo hierarquizado, moldada nos padrões da Escola Nacional de Arquitetura (VIDOTTO, 2014, p. 48) no qual alunos aderiram a mestres com os quais se identificavam por razões das mais variadas, das políticas às plásticas.

Maitrejean seguiu as propostas de Artigas, com quem manteve uma longa relação de amizade, mas foi com Abelardo Riedy de Souza com quem começou a trabalhar desde o $2^{\circ}$ ano da escola, ainda que nem sempre compartilhasse das propostas plásticas do arquiteto carioca. Era muito bom desenhista e isso lhe valeu o trabalho de estagiário no escritório do professor, desde 1950 até finalizar o curso em 1953, passando em 1955, a arquiteto colaborador. Participou neste escritório de projetos para a Companhia Nacional Imobiliária (CNI), e para os edifícios Três Marias e Nações Unidas, ambos na Av. Paulista. Seu desempenho no escritório de Abelardo Ihe ofereceu outras possibilidades, como a de trabalhar como desenhista para Lina Bo Bardi, que precisava de alguém para desenhar as pranchas da sua residência no longínquo Morumbi.

Em novembro de 1954, por indicação também de Abelardo de Souza (CAMARGO, 2015, p. 4), tornou-se o primeiro docente da FAU-USP egresso da mesma instituição. Foi assistente na Cadeira no 16, "Composição de Arquitetura-Pequenas Composições", da qual era Regente Abelardo, atuando no $2^{\circ}$ ano. A Cadeira $n^{\circ} 16$ já tinha sido ocupada por Vilanova Artigas, ${ }^{3}$ desde 1948 e por Hélio Duarte até 1953. Tratava-se de uma disciplina importante, pois a Cadeira de Composição, herdada da Politécnica, era a que diferenciava a formação entre engenheiros e arquitetos (engenheiro-arquiteto), pois nela o objeto de estudo e ensino eram as edificações.

Maitrejean, não só desempenhou atividades de docente, como também participou do constante debate sobre o ensino da arquitetura, tema que ainda lhe preocupa. Em 1955 intermediou as relações entre a FAU-USP e o IAB por conta da aprovação do primeiro Regulamento da Faculdade e sua autonomia. (VIDOTTO, 2014, p. 123) À época o IAB tinha enorme protagonismo, e interesse, em relação ao ensino da arquitetura, pois a entidade afirmava que cabia aos arquitetos já formados decidirem sobre esse tema (VIDOTTO, 2014, p. 181).

Esses primeiros 10 anos da FAU-USP foram atribulados porque a faculdade estava se formando junto com a profissão do arquiteto, que conhecia um momento de afirmação. O sucesso internacional da Arquitetura Moderna Brasileira no período, com publicações internacionais registrando as suas qualidades contribuíam para articular 
4 Até a reforma de 1962 a FAU-USP não teve nenhum diretor arquiteto.

5 Formado em 1951, pela Faculdade de Arquitetura Mackenzie, entrou como professor nessa escola em 1958. "Em 1959, Roberto Cerqueira César e Luiz Roberto Carvalho Franco convidam Millan para ocupar uma vaga na cadeira de Composições do $4^{\circ}$ ano da FAUUSP, que estava disponível após remanejamento de professores iniciado com a saída de Rino Levi da escola no ano anterior". (MATERA, 2005, p. 94)

6 Formado em 1957 pela FAU-USP, entrou nessa escola como Professor Assistente em 1958. Grinover foi aluno de Maitrejean.

7 No texto sobre o Ateliê Integrado redigido por Millan (1962) consta a informação de que também participou dessa comissão Gian Carlo Gasperini, contudo Gasperini não era professor da FAU-USP em 1962, pois só ingressou na carreira docente, com Professor Assistente, em 1974, como consta no seu Currículo Lattes. Maitrejean, em depoimento a estes autores, afirmou que não se recordava dessa participação. Ainda assim, há dados de que Gasperini participava das atividades de FAU-USP no início dos anos 1960, provavelmente por iniciativa de Plínio Croce, e é signatário de uma carta, de 11 de setembro 1961, reclamando do afastamento do diretor Anhaia Mello. Começou o mestrado em 1963, finalizando em 1966.

8 Departamento de História da Arquitetura e Estética do Projeto, o Departamento de Projeto e o Departamento de Tecnologia.

9 A história dos decretos de afastamento dos professores da USP pode ser consultada em ASSOCIAÇÃO DOS DOCENTES DA USP (2004, p. 45-50). a profissão à formação moderna. Entretanto, em termos sociais e institucionais, havia um desnível entre o prestígio das qualidades da arquitetura produzida e o reconhecimento da profissão. Maitrejean lembra que nos anos 1950, por exemplo, não existia a carreira de "arquiteto" na administração pública e que a contratação deste tipo de profissional só começou no final da década com atividades relacionadas ao Departamento de Obras Públicas (DOP). A luta de Artigas pelo reconhecimento da profissão e pela participação ativa de arquitetos na formação dos futuros profissionais era intensa, tanto na Faculdade, onde a luta era para ter um diretor arquiteto, ${ }^{4}$ como no $I A B$, onde as lutas dos alunos por uma escola de arquitetos para arquitetos eram pauta permanente.

Vale registrar que a luta pelo aprimoramento da formação e reconhecimento da profissão de arquiteto e urbanista, articulada a difusão da arquitetura moderna, também, era interpretada como uma luta pelo desenvolvimento do país. O modernismo arquitetônico, ligava-se a modernização material. O horizonte almejado, era o da industrialização da construção, setor no qual os arquitetos, além de representarem a modernização através das obras modernas, poderiam contribuir para a sua efetivação.

Em 1962, participou, junto com Carlos Millan ${ }^{5}$ e Lúcio Grinover, ${ }^{6}$ da "Comissão de Estudo do Ateliê", que formava parte do Plano Reforma Curricular. ${ }^{7}$ Um programa que pretendia substituir as disciplinas isoladas dos planos de 1948, da frustrada reforma de 1957 e do Currículo de 1961, criando um eixo organizador do ensino, apoiado sobre as velhas Cadeiras de Composição (nas quais Maitrejean e Millan tinham sido professores assistentes), agora transformadas em disciplinas de projeto.

Ainda que a reforma de 1962 concretiza-se a "introdução do atelier de projetos como cerne do ensino de arquitetura e urbanismo, para o qual se voltavam todas as disciplinas, em uma estrutura que unificava a formação profissional do arquiteto e do urbanista" (VIDOTTO; MONTEIRO, 2015, p. 22), ele nunca foi realmente implantado com essa dimensão proposta. Contudo, foi importante para o processo de reformulação geral do ensino na FAU-USP que determinou a reforma curricular de 1962, protagonizada por João Batista Vilanova Artigas, Carlos Millan e Lourival Gomes Machado, entre outros. Uma reforma que estruturou a Faculdade em três Departamentos: de História, de Projeto, e de Técnica. ${ }^{8}$

Ainda, fora estas atividades ligadas à docência e à estrutura do ensino, Maitrejean trilhou o caminho da representação da FAU perante o Conselho Universitário da USP. Foi Conselheiro Universitário desde a 616 a sessão, de 21 de outubro de 1968, até a 664ª sessão, de 29 de abril de 1969 (RANIERI, 2005, p. 374-380). Justamente a data na qual foi aposentado compulsoriamente pelo Decreto Presidencial de 29 de abril de 1969, um dos dois decretos assinados pelo general Artur da Costa e Silva, nesse ano que, amparados no vergonhoso Ato Institucional $n^{\circ}$ 5, de dezembro de 1968, cassaram, dentre vários opositores do regime militar, 24 professores da USP, incluindo o Reitor em exercício, Helio Lourenço. Da FAU-USP, entre os dias 29 e 30, além de Maitrejean, foram cassados Vilanova Artigas e Paulo Mendes da Rocha. ${ }^{9}$ Curiosamente, só o nome de Artigas constava nas listas dos dois decretos (28 e 29 de abril). Mendes da Rocha e Maitrejean, não constavam da lista do dia 28. Contudo, apareceram na lista do dia 29. Maitrejean intui que sua expulsão, a diferença da de Artigas que foi evidentemente por motivações político-partidárias, se deveu a sua exclusivamente à 
sua atuação como Conselheiro Universitário, pois não era filiado ao Partido Comunista Brasileiro, como Artigas, ou a qualquer outra organização de esquerda.

Seja qual fosse a razão das injustas demissões, e de forma triste, como afirma Sergio Ferro (2015) "não houve quem protestasse por parte da USP, nem da FAU-USP pela ignomínia desse ato arteiro e politicamente dirigido", como afirmou Maitrejean (2015, 8:39-8:50), muito tempo depois, a "eliminar o esquerdismo da intelectualidade que dava aula na USP. Ela atingia especificamente as lideranças de esquerda".

A cassação, para Maitrejean e para todos os docentes, afora os demais, foi traumática, obrigou de forma compulsória a rever a relação da arquitetura com a dimensão política e a própria inserção profissional, como será visto. Mas Maitrejean não pretendia deixar a docência, que fazia parte de sua dedicação à arquitetura. Após uma década, em 1977 se incorporou à Faculdade de Arquitetura e Urbanismo de Santos (FAUS), da qual foi também Diretor. Na FAUS teve a oportunidade de atuar junto a outros colegas que compartilhavam seu entusiasmo pelo ensino da arquitetura e do urbanismo nos moldes disciplinares da FAUUSP de 1962, como Oswaldo Corrêa Gonçalves. Permaneceu ligado à FAUS até 1983.

O lento processo de redemocratização do Brasil permitiu que Maitrejean voltasse à FAU-USP. Entretanto, esse processo não foi fácil, e, sobretudo, nem moralmente justo. Assim, apesar da revogação dos atos institucionais pela Emenda Constitucional $n^{\circ} 11$ de 13 de outubro de 1978, a reversão dos danos causados demorou e esteve coalhada de empecilhos. O primeiro deles foi a Lei 6683 de 28 de agosto de 1979 de anistia parcial, que obrigava aos expurgados a solicitarem a reintegração às atividades que exerciam quando da cassação, contudo, condicionada à existência de vagas e ao interesse da administração da instituição ou de seus superiores na reintegração de cada um dos solicitantes. (GRECO, 2003, p. 299) Professores e pesquisadores da USP, e de outras instituições, consideraram as exigências como "obstáculos" à reintegração plena dos expurgados, e assim o manifestaram em documento enviado à Comissão Mista sobre Anistia do Congresso Nacional antes da aprovação da lei (GRECO, 2003, p. 303-304).

Os três professores da FAU-USP tiveram assim que esperar até o segundo semestre de 1980 para conseguir seu regresso à escola que tinham ajudado a fundar e construir 30 anos antes. Como se isso não fosse o bastante, o retorno à FAU foi "por baixo", sendo readmitidos sob o constrangimento de "receber o status de docentes em início de carreira", ou seja, professor auxiliar de ensino (CAMARGO, 2015, p. 6). Em que pese essas condições, Maitrejean se reintegrou como professor no Departamento de Projeto, onde atuou até sua aposentadoria em 1987. A aposentadoria, desta vez, não foi uma imposição administrativa, mas uma decisão consciente do próprio professor que não encontrava, naquela FAU de finais dos anos 1980, o espírito renovador e libertário que tinha prevalecido nos anos anteriores ao golpe militar de 1964.

Em 1998, quando os 50 anos da FAU-USP foram comemorados com a exposição Cinco Décadas de Arquitetura: Uma Leitura, realizada no Museu Brasileiro da Escultura, entre outros festejos, Maitrejean foi convocado por Abrahão Sanovicz, curador geral da exposição, para organizar a apresentação da primeira década da escola (1948-1958). Colaborou, nessa empreitada, com outros colegas mais jovens, como 
Maria Helena Flynn, Roberto Portugal Albuquerque, Milton Braga e Fernanda Bárbara, que, respetivamente, foram responsáveis pela organização dos períodos: 1959-68, 1969-78, 1979-88 e 1989-98.

Mas, Jon Maitrejean não conseguiu nunca esquecer sua vocação docente e, em 1994, voltou à universidade, desta vez, como professor de Projeto de Arquitetura do curso de Arquitetura e Urbanismo da Universidade São Judas Tadeu, onde continua sua incansável atividade docente até hoje.

\section{Participação em entidades e órgãos deliberativos}

Maitrejean manteve desde os anos 1950 uma intensa participação nos órgãos de defesa da profissão do arquiteto. Engajou-se primeiro no IAB-SP, o Instituto dos Arquitetos do Brasil, departamento de São Paulo, onde começou como "sócio aspirante", uma categoria inventada no início dos anos 1950 para incorporar aos ativos os estudantes de arquitetura da FAU-USP e do Mackenzie que queriam participar das atividades do Instituto. A primeira ação que os estudantes desenvolveram foi criar o NEDAB, o Núcleo de Estudos e Divulgação de Arquitetura no Brasil, que organizava exposições sobre a jovem arquitetura brasileira e convocava personalidades da época para debater sobre a realidade nacional. Os encontros do NEDAB foram muito bem-sucedidos, promovendo ainda mais a ativa vida social e cultural do IAB, mas, sobretudo, deram visibilidade e força aos recém-formados arquitetos para ir ocupando lugares de comando no Instituto.

Como decorrência dessa atuação como estudante, formado, Maitrejean tornou-se cedo, em 1955, Conselheiro Diretor, junto com o colega Jorge Wilheim, e os mais velhos como: Ariosto Mila, Wilson Maia Fina e Eduardo Kneese de Mello. Posteriormente, foi $2^{\circ}$ Secretário, na gestão de Júlio José Franco Neves (1966-67), aí numa chapa de coligação entre representante de direita e de esquerda, sob o regime militar, com Neves de um lado e Wilheim do outro. Maitrejean participou junto à equipe de Jorge Wilheim. Depois, foi Conselheiro Superior (titular) nas gestões de Paulo Mendes da Rocha (1972-73) e de Cesar Galha Bergsrtom Lourenço (1980-81). Finalmente, formou parte da diretoria do IAB-SP na gestão de Fábio de Moura Penteado (1994-95) (IAB, 2018).

Foi, também, Vice-diretor da Divisão Nacional de Ensino de Arquitetura do IAB/Brasil, entre 1965 e 1966.

Desenvolveu atividades também em outras instâncias vinculadas à profissão, como o Sindicato dos Arquitetos de São Paulo (SASP), fundado em 1971, do qual foi Presidente na gestão 1978-80, ou ainda o Conselho Regional de Engenharia e Arquitetura de São Paulo (Crea-SP), do qual foi conselheiro, como representante do IAB-SP, de 1970 a 1973; novamente entre 1973 e 1976 quando foi Membro da Comissão de Planificação e Orçamento e da Comissão de Atribuições no exercício 1975-76. No período 198285, ocupou o cargo de $1^{\circ}$ Secretário no exercício de 1984-85. Sua última participação foi entre 1985 e 1988, ocupando o cargo de $1^{\circ}$ Vice-Presidente.

Maitrejean foi, por 10 anos, conselheiro no Conselho de Defesa do Patrimônio Histórico, Artístico, Arqueológico e Turístico do Estado de São Paulo (Condephaat). Primeiramente, como representante do IAB nos colegiados de números 21 (08/2000 a 07/2002), 22 (09/2002 a 09/2004); e 23 (05/2005 a 09/2006), todos eles presididos por 
10 Tombado em março de 2018 pelo Conpresp.
José Roberto Fanganiello Melhem. Ainda, como representante do IAB, foi conselheiro no $24^{\circ}$ Colegiado (10/2006 a 07/2007), sob a presidência de Carlos Alberto Dêgelo; e no $25^{\circ}$ Colegiado (03/2007 a 12/2008), sob a presidência de Adilson Avansi de Abreu. Em 2008, voltou a ser nomeado conselheiro, mas desta vez indicado pela Secretaria de Cultura do Estado de São Paulo (Unidade de Preservação do Patrimônio Histórico - UPPH), sob a presidência de Rovena Negreiros. Terminou seu mandato em 2010 (CRISPIN, 2014).

No Conselho, atuou, por exemplo, no famoso processo de remembramento de lotes da Rua Livreiro Saraiva, de 2008, que colocou em questão a possibilidade de desfigurar o bairro jardim. Maitrejean se manifestou contrário ao remembramento, o Condephaat manteve esse entendimento, embora tenha sugerido que o remembramento poderia acontecer no subsolo, critério defendido pelo arquiteto. No relatório sobre o tombamento do bairro do Pacaembu, Maitrejean aponta questões de sentido comum que dificilmente são colocadas em pauta nos dias atuais. Por exemplo, questionando a proposta do Departamento Técnico perguntou qual era o sentido de exigir o plantio de cinco árvores dentro dos lotes de novos projetos: "a maioria da residência não possui árvores - afirmou Maitrejean - [as ruas é que são arborizadas] [...] Novamente lembramos que preservar não é melhorar. Como explicar que num bairro tombado com residências sem árvores, agora exijamos cinco?" (ESTADO DE SÃO PAULO, 2010, p. 102) Em 2006 foi relator, também, do processo de tombamento do edifício Abaeté, ${ }^{10}$ obra de Abrahão Sanovicz, embora em 2013, quando o processo finalmente chegou ao Colegiado, foi retirado da pauta, para análise junto com outro processo que tratava do estudo de tombamento de edificações no bairro de Higienópolis (JUSBRASIL, 2010, online).

Suas convicções sobre tombamento são fortes. Pensa que a figura do tombamento é uma "figura autoritária", que carrega sobre o proprietário do imóvel tombado todo o ônus da conservação do bem, quando deveria ser o poder público quem deveria assumir o ônus da preservação. O tombamento é um reconhecimento por parte da sociedade de que um bem é valioso para a ela, assim corresponderia à sociedade, através das instâncias governamentais assumir os custos dos tombamentos. Há nessa concepção um entendimento do Estado, que extrapola a questão patrimonial, mas que, no caso, o interpreta como o órgão que deve ser responsável, ou deve abrigar os anseios pela definição e constituição da dimensão cultural da própria sociedade, acima de eventuais disputas e interesses específicos. Isso não impede que considere outras situações, que por ventura tenha outros protagonistas. Maitrejean cita como um bom exemplo de conservação do patrimônio construído o casarão que pertenceu à família de Ramos de Azevedo, tombado como patrimônio histórico em nível municipal e estadual em 1985. A construção permaneceu fechada por muitos anos, mas em 1988 foi vendido para o Grupo Editorial Global, que a mantém até hoje.

\section{O livre exercício da profissão}

Em 1955, no início da carreira, Maitrejean trabalhou em parceria com Daisy Igel (1928), recém-chegada dos Estados Unidos, onde estudou no Chicago Institute of Design (inicialmente chamado de New Bauhaus), o que lhe deu a oportunidade de ter "aulas com Mies van der Rohe, Buckminster Fuller e Konrad Wachsmann, e contato próximo com Josef Albers" (NOBRE, 2010, p. 19). A parceria com a designer rendeu 
11 Informação verbal subministrada em entrevista realizada no dia 27 de julho de 2018 com os professores Fernando G. Vázquez Ramos e Miguel A. Buzzar.

12 "Eu era chefe de mim mesmo, era eu que pensava e desenvolvia os produtos, assessorado pelos técnicos da fábrica". Informação verbal, em entrevista aos autores em 3 de agosto de 2018. obras importantes, como as residências Israel Klabin e Pedro Franco Piva e o centro de distribuição da Ultragás, cujo projeto foi publicado na revista Acrópole (1955, p.2123), onde Igel foi mencionada em primeiro lugar como projetista. O trabalho com a designer foi farto, ainda que centrado em residências, e a associação durou até 1966, quando Igel voltou para o Rio de Janeiro para assumir um cargo de docente na Escola Superior de Desenho Industrial (Esdi), que tinha sido criada em 1963.

Outros colaboradores dessa primeira época foram os arquitetos Helmut Hein, que teve participação nas obras do Plano de Ação do Governo Carvalho Pinto (CAMARGO, 2016, p. 198), e a curta sociedade com Armando Peres Gomes, com quem criou a Construtora Construart, dedicada a construir casas para venda comercial, como a publicada na revista Acropole (1968), pois, como afirma Maitrejean, "na época não havia grandes obras para fazer" (SAFLEX, 1988), ou, pela sua atuação política, não possuía conexões para projetá-las.

Para o PAGE, contratado pelo Instituto de Previdência do Estado de São Paulo (IPESP), projetou as Escolas Estaduais: Maria Pereira de Brito Benetoli, em Auriflama; Senhora de Aparecida, em Jaboticabal; e Prof. Reynaldo Galvão, em Paraguaçu Paulista. Além do Fórum Santa Isabel e do Posto de Saúde em Cunha.

Continuando o trabalho de projeto de escolas, projetou para o Fundo Estadual de Construções Escolares (FECE), criado pelo PAGE, no início dos anos 1960, as Escolas Estaduais: Dr. Euphly Jales, em Jales; Profa. Carlota de Negreiros Rocha (1962-67), em Marília; e Zulmira da Silva Salles, em São José do Rio Preto. (MELLO, 2012) Assim como, para o Departamento de Obras Públicas (DOP), o Centro Educacional de João Ramalho, em São Bernardo do Campo.

No início dos anos 1960, Maitrejean trabalhou também junto com outros arquitetos em alguns concursos de projetos, como o da Assembleia Legislativa de Minas Gerais (1962), que desenvolveu com Francisco Petracco, Nelson Morse e Telesforo Cristofani. Curiosamente, não participou de nenhuma das equipes que postularam projetos para o concurso do Plano Piloto da Nova Capital, segundo seu depoimento, "não se sentia capacitado para pensar uma cidade" (Informação verbal) $)^{11}$.

Em 1969, após sua vexaminosa aposentadoria compulsória da FAU-USP, começou a trabalhar para a Duratex S/A Indústria e Comércio, onde permaneceu até 1972 como chefe $^{12}$ da Divisão de Produtos Novos. A Duratex, empresa fundada em 1950 com a finalidade de produzir chapas de fibra de madeira, diversificou suas atividades em finais dos anos 1960, para tanto, além de incorporar novas frentes de produção de materiais de construção, como a fabricação de metais (Deca) ou de cerâmicas (Louças Jundiaí), montou uma divisão de ideação de aplicações de seu principal artigo, a chapa de fibra de madeira, em objetos, os mais variados, destinados à construção civil.

Há um comentário necessário sobre a participação de Maitrejean na Duratex. O projeto nacional-desenvolvimentista que a intelectualidade, sobretudo a de esquerda, abraçou até o golpe militar de 1964, apenas seria possível com o aprimoramento da democracia. Essa articulação entre desenvolvimento econômico de base industrial e componente política democrática, Guido Mantega nomeou como "Modelo Democrático-Burguês", que afirmava que a industrialização, porque vinculada aos 
13 Idem.

14 Idem. objetivos da burguesia industrial, que por definição, também seria portadora da democracia, necessitava derrotar o arcaísmo representado pelas oligarquias agrárias e pelo setor agroexportador, politicamente, conservadores. O golpe militar, a favor e articulado pelos últimos, economicamente, aniquilaria a indústria em formação. A realidade mostrou-se outra, sem democracia, mantendo e aprofundando o caráter socialmente regressivo da industrialização brasileira (industrialização com baixos salários), o regime militar manteve o perfil do desenvolvimento dependente do país. Como vários outros colegas, que comungavam ideais nacional-desenvolvimentistas, Maitrejean, por caminhos diversos do que imaginava realizou trabalhos, que em tese fugiam das formulações teóricas. Trabalhos percebidos por vezes, como contradições do sistema que deveriam ser exploradas.

Assim, a experiência mostrou-se importante para o arquiteto, que se viu frente a uma nova dimensão da industrialização, a da invenção, estudo e desenvolvimento de novos produtos que utilizassem as chapas fornecidas pela empresa como matéria prima. $\mathrm{E}$ não foram poucos. Entre eles, Maitrejean ${ }^{13}$ destacou as "formas para moldar lajes de concreto" que adotaram um formato curvilíneo criando uma laje tipo abóbada catalã, uma adaptação das chapas planas graças a sua capacidade de serem moldadas com calor. Maitrejean usou essas formas na sua residência para construir a laje acima da garagem. Também desenvolveu chapas decoradas com formato de azulejos, mais precisamente, "paredes azulejadas", pois as chapas mediam 2,44 x 1,22m. Para esse produto, Maitrejean trabalhou em colaboração com duas das divisões da empresa, a que produzia chapas (Duratex) e a que produzia tinta (Duraplac, subsidiária criada em 1968), além de engenheiros mecânicos que adaptaram as máquinas da empresa para poder criar o produto. As placas lisas tinham que ser riscadas transversal e longitudinalmente para formar a grade dos azulejos (imitando a junta de azulejos montados numa parede) para depois serem pintadas, com a decoração dos azulejos, e finalmente protegidas contra cupins.

Mas, a empresa não estava interessada no desenvolvimento destes produtos, sua intenção, funcionando como uma espécie de incubadora, era a de viabilizar a formação de terceiros que fossem capazes de usar os produtos da Duratex como matéria prima, assim pouco tempo depois o arquiteto deixou a empresa, mas a experiência acumulada nunca deixou o arquiteto que se lembra dessa etapa de sua vida como um momento feliz de aprendizado. ${ }^{14}$ Sua própria residência obra de 1971 (Figura 2), no bairro do Caxingui em São Paulo, "explora de maneira criativa as soluções possíveis da utilização de elementos industrializados" (BELLEZA, 1997, p. 333).

Após Duratex, o arquiteto se vincula, por um curto período, de 1972 a 1973, como Diretor do Departamento de Arquitetura, à firma Serete S.A. Engenharia, uma companhia de origem francesa que tinha desenvolvido, junto com Jorge Wilheim, o Plano Preliminar de Urbanismo de São Paulo, 1964. Nessa companhia dirigiu os trabalhos de projeto das Centrais de Abastecimento de Belém (CEASA), no Pará, e o projeto de autoria de Paulo Mendes da Rocha para o estádio da Fundação Estadual do Esporte, Serra Dourada, Goiânia; assim como, o Centro de Distribuição da empresa Colgate Palmolive.

Aproveitou também de uma viagem realizada junto ao colega Georges Salim Sallouti (1936-1988), seu futuro sócio, para ver as obras de construção de cidades na banlieue 
Figura 2: Residência do arquiteto Jon Maitrejean. Fachada principal, São Paulo, 1971. Fonte: Foto de Marco Mancini. Acervo do arquiteto Shieh Shueh Yau, cordialmente cedida.

15 Maitrejean em conversa com os autores mencionou que foi "contratado para resolver projetos e teve que viajar bastante". Entrevista de 27 jul. 2018.

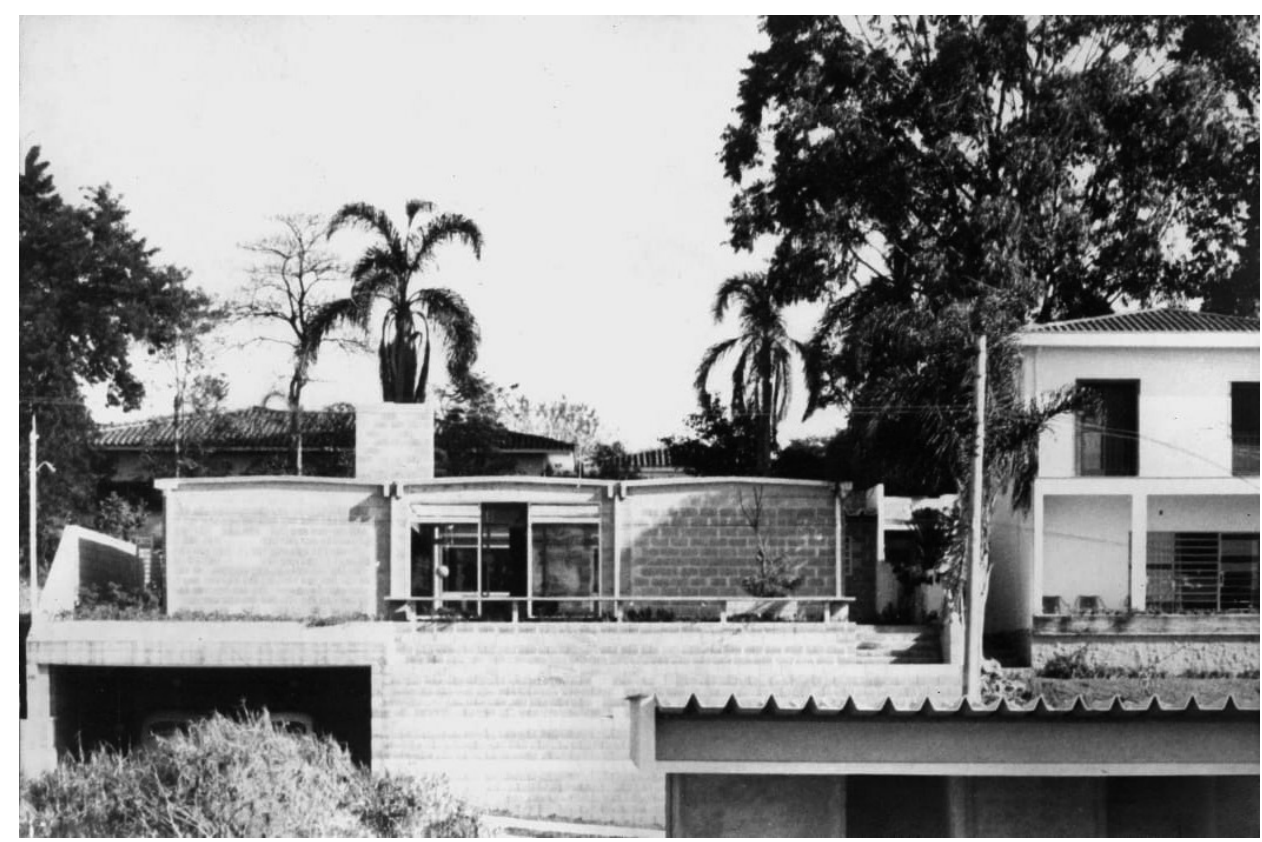

de Paris, que a matriz francesa da Serete promovia quando a França era governada por Georges Pompidou e as periferias criticadas por Henri Lefebvre no seu famoso Le droit à la ville, de 1968.

O aprendizado na Serete foi muito importante, segundo suas palavras, não só porque o familiarizou com trabalhos de grande porte, sobretudo ligados a questões de abastecimento, mas também porque foi nessa empresa que entrou em contato com Sallouti, que nela trabalhava desde 1971. Ambos saíram da empresa em 1973, Sallouti para os Supermercados Peg-Pag, que mudou o sistema de vendas de varejo, e Maitrejean para ocupar o posto de Diretor de Arquitetura na empresa Quatro Rodas Empreendimentos Turísticos, 15 onde, em um ano intenso, participou de diversos projetos de hotéis: em São Luiz do Maranhão, na Praia de Calhau, Piauí, o Hotel de Natal, em Ponta Negra, RN, o Hotel Olinda, na Praia da Casa Caiada, em Pernambuco e o Hotel de Salvador, na Praia de Itaporã, na Bahia. Maitrejean morou um tempo em Recife, justamente para poder tocar essas obras no nordeste.

Mas, nesse meio tempo, não deixou de desenvolver trabalhos como arquiteto independente, aproveitando a ampla formação que o percurso por essas empresas tinha Ihe aportado. Em 1968, projetou, o edifício da Câmara Municipal para a Prefeitura Municipal de Jundiaí, com seu belo Salão Nobre do Plenário.

Outros colegas com os quais trabalhou, e manteve uma rápida sociedade no início dos anos 1970 foram Dicran Kassardjian, José Alberto Soares e Helena Afanasieff, no projeto do Estádio Municipal de Serra Dourada em Goiânia (1973). Segundo Maitrejean (SAFLEX, 1988): "A gente montava escritório, uniam-se três ou quatro arquitetos, 
Figura 3: Estudo Hotel Hollyday Inn. Urca, Rio e Janeiro, Maitrejean \& Sallouti Associados Arquitetos (com Cláudio Cavalcanti), 1983. Fonte: Acervo do arquiteto Jon Maitrejean, cordialmente cedida. faziam as casas dos parentes e amigos e não havia mais serviço". Essa prática continuou ainda durante a sociedade com Sallouti, como no caso da colaboração com Cláudio Cavalcanti, com quem projetaram, em 1983, um Hotel Hollyday Inn no terreno do antigo Cassino da Urca, no Rio de Janeiro, que não teve continuidade pelos evidentes problemas legais e patrimoniais que o empreendimento demandava (Figura 3).

Mas, finalmente, aproveitando um terreno que a rede de Supermercados Peg-Pag tinha comprado na Marginal Pinheiros, em 1974, trazido por Sallouti, este e Maitrejean projetaram, em 1975, o que posteriormente seria conhecido como Edifício Passarelli (Figura 4). Um projeto que partiu da premissa de uma grande alteração urbanística, da região, que retalharia o terreno, deixando só uma extremidade livre para construção de um edifício de escritórios com um estacionamento em nível. No final da década de 1970 a Peg-Pag vendeu o terreno, e o projeto para Sylvio Passarelli, que o transformou na sede de sua empresa, que pediu algumas alterações aos arquitetos, como a inclusão

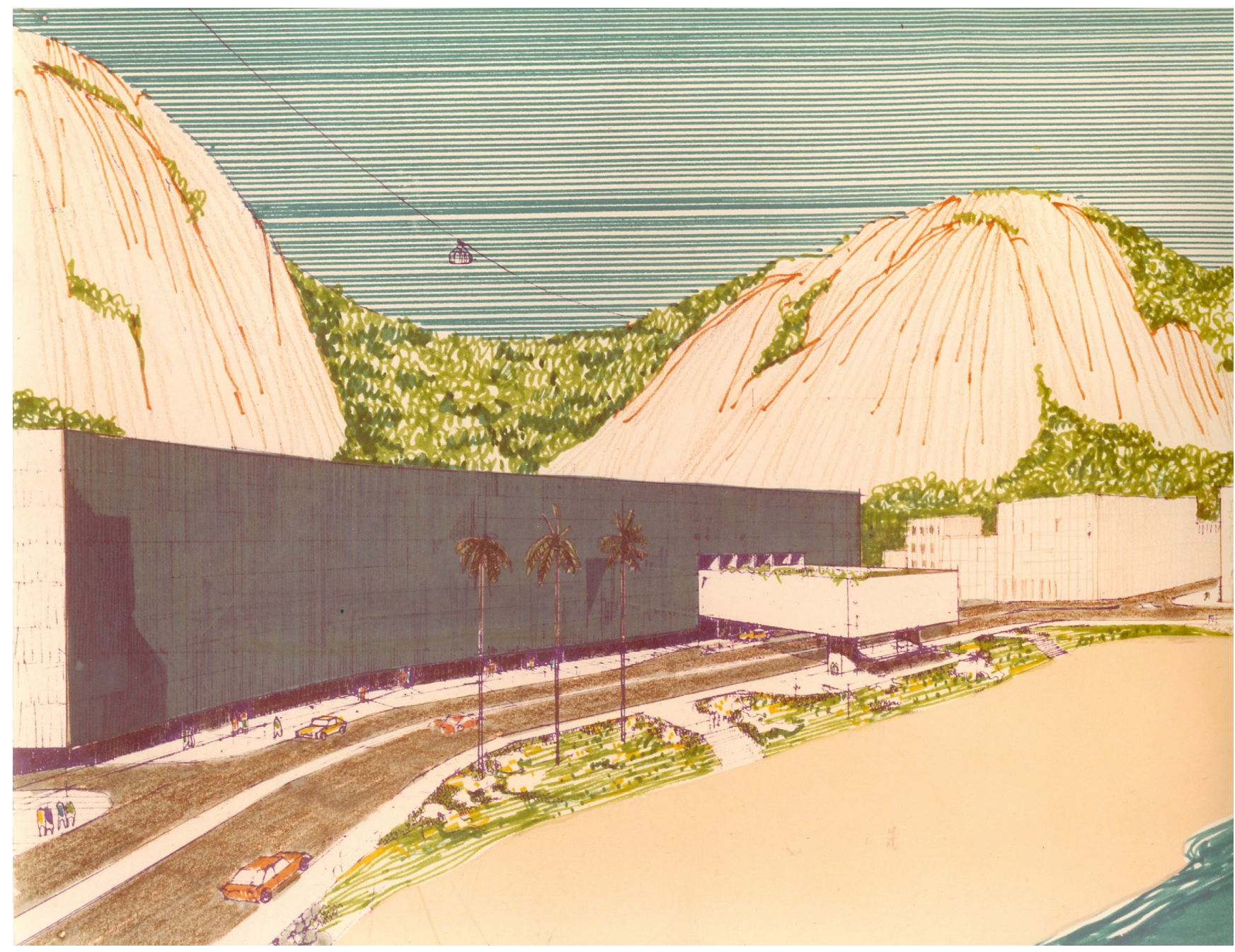

risco. $16 \_2$ 


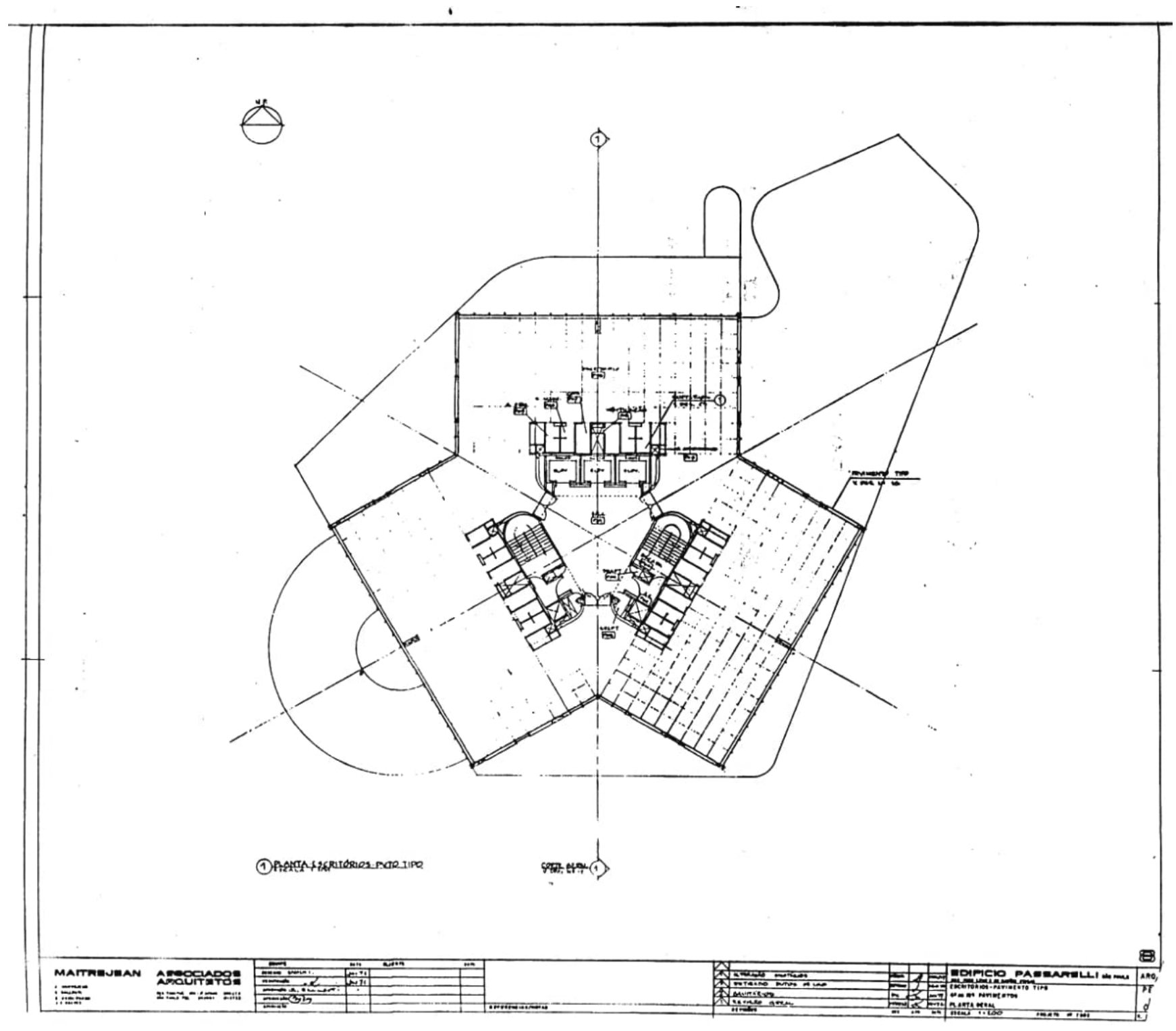

Figura 4: Edifício Passarelli. Planta do andar tipo na prancha oficial do escritório Maitrejean \& Sallouti. Estudo para o anteprojeto de 1975. Fonte: Acervo do arquiteto Jon Maitrejean, cordialmente cedida. de uma área maior de garagem subterrânea. Este projeto foi desenvolvido no mesmo momento que o escritório começava a projetar o Crowne Plaza Hotel, em São Paulo, o que deu um enorme fôlego ao novo escritório.

Com o edifício Passarelli, o périplo pelas empresas privadas e pela atividade solitária findaria já em 1975, com a associação com o arquiteto Georges Sallouti. Juntos fundaram o escritório Maitrejean \& Sallouti Associados Arquitetos, um escritório que "se dedica à elaboração de projetos para novos programas de uso, em outra escala de construção, projetando grandes centros de abastecimento, de distribuição e supermercados" (JUNQUEIRA, 2016, p.184). 
17 Entrevista com os autores em 27 jul. 2018.
Sallouti, de origem palestina (nascido na cidade de Haifa), tinha-se formado arquiteto, em 1967, pelo College of Enviromental Design da Universidade de Califórnia em Berkeley, e dispunha de respeitável experiência profissional nos EUA, com projetos de Malls (Shopping Centers). Sua família tinha emigrado da Palestina para o Brasil nos anos 1950 e Sallouti veio para São Paulo convidado para trabalhar no escritório de Henrique Mindlin, ${ }^{16}$ em 1968.

Nesse escritório, onde trabalhou até 1971, participou de projetos como a Fábrica da IBM, o imponente Hotel Sheraton do Rio de Janeiro, e o banco da Lavoura, em São Paulo. Mas, se vinculou também a várias empresas de engenharia que aproveitaram sua experiência e formação, como as mencionadas Serete e os Supermercados Peg-Pag, e ainda a Milder-Kaiser Engenharia, subsidiária da Kaiser International, empresa na qual tinha trabalhado nos EUA, entre 1962 e 1968. Mas, certamente, o aprendizado maior foi nos Supermercados Peg-Pag, pelo menos tendo em conta o desenvolvimento do escritório que montou em sociedade com Maitrejean, porque o know-how da montagem de lojas de varejo e de atacado, que seria um "nicho" de projeto do escritório, veio daí. Ainda assim, Sallouti era um arquiteto bastante versado, como demonstra sua participação no concurso para o Pavilhão de Osaka (1970), junto à equipe de Flávio Mindlin Guimarães, Marklen Landa e Roberto Loeb, que foi uma das cinco que compartilharam o $4^{\circ}$ Prêmio (FIALHO, 2007, p. 134).

Maitrejean manteve a sociedade com Sallouti até o falecimento deste em 1987, embora Maitrejean tenha continuado projetando no mesmo escritório até 2013. Um de seus últimos projetos foi em São Carlos, o prédio da loja Tenda (antiga Vila Nova), outro em Diadema, onde reformou uma antiga fábrica para transformá-la num Supermercado Assaí. Apesar de ter entrado no século XXI projetando, nunca usou computador, continuou desenhando a mão, sem precisar do Autocad, e sobre o BIM, diz que "o projetista tem que ser um técnico em construção para poder usá-lo, pois não é uma ferramenta para conceber projetos, mas só para definir a obra construtivamente" (Informação verbal) ${ }^{17}$.

O forte do escritório Maitrejean \& Sallouti Associados Arquitetos, como apontado, foram os empreendimentos comerciais, especialmente edificações para grandes redes varejistas e de supermercados, como: Alô Brasil, Atacadão, Assaí, Big, Paes Mendonça, Messias, Vila Nova ou Tenda, e indústrias, como a Magnafer e a Constanta Eletrotécnica S/A. Mas, o escritório teve uma atividade bem diversificada, produto da experiência de seus sócios e dos conhecimentos adquiridos no desenvolvimento de diversas tipologias arquitetônicas, associado a uma metodologia de projeto, e de produção de projetos, apurada e precisa que permitia um desenvolvimento eficiente de muitos projetos por ano. Projetos, por certo, de grande tamanho e complexidade, tanto funcional como construtiva.

Alguns deles, como a loja para o Supermercado Sé, de 1983, em São Paulo, "chamado de 'pós-moderno' na época de sua inauguração, que inovou a linguagem de edificações desse tipo, associando uma linguagem diferenciada do tradicional 'galpão' de vendas", (BELLEZA, 1997, p. 335), ou ainda o Hipermercado Paes Mendonça, de 1981, em Aracajú, que "explora mais especificamente o monobloco como invenção em função das dimensões do terreno" (BELLEZA, 1997, p. 335), são exemplos apurados das transformações que a técnica da industrialização, junto à experiência profissional e à capacidade criativa da dupla Maitrejean e Sallouti poderia dar. 
Figura 5: Vista aérea do Atacadão. Maitrejean \& Sallouti Associados Arquitetos, 1984. Fonte: Revista Projeto, 1985, p. 84
Alguns problemas, desse tipo de programa, eram cruciais para o bom desenvolvimento dos projetos. O primeiro era a própria implantação, pois sendo normalmente lojas construídas em terrenos de grandes dimensões a relação com a cidade era fundamental era de fundamental importância, em termos de acesso e em termos da conformação do edifício em relação ao tecido urbano. Assim, a resolução do acesso, pensando que deveriam ser separados acessos de clientes (de carro) dos de abastecimento (caminhões, ou ainda carretas), em geral, determinava uma organização do projeto com estreita relação ao viário e à organização dos fluxos da cidade. Depois, no edifício propriamente dito, as questões das instalações, principalmente o escoamento das águas pluviais, exigiam soluções específicas, pois as coberturas enormes, algumas com mais de $70 \mathrm{~m}$ de comprimento, que usavam telhas metálicas contínuas, podiam causar problemas e comprometer o correto escoamento das águas. Fora os problemas técnicos que essas enormes coberturas acarretavam, como a dilatação das telhas que podia chegar a $15 \mathrm{~cm}$.

Mas, não eram só os problemas construtivos, próprios da profissão, que o escritório pensava. Analisando a vasta produção, se percebe com facilidade que "é um dos arquitetos desta geração [moderna] que se envolveu mais intensamente com as questões da industrialização na arquitetura e na construção civil" (JUNQUEIRA, 2016, p. 184). O sistema desenvolvido para o Atacadão, uma rede varejista fundada em 1962, na cidade de Maringá, por Alcides Parizotto, quem a dirigiu até 1991. Foi na interação pessoal com este empresário que Maitrejean pensou e planejou o novo sistema de estocagem de mercadorias: um sistema que acabava com os "depósitos", transformando toda a área da loja no local de armazenagem das mercadorias. O sistema funcionava porque integrava máquinas (empilhadeiras) e pellets no processo de armazenagem. Os edifícios das lojas eram grandes contenedores que precisavam de algumas especificidades técnicas, como a perfeição da execução dos pisos para o bom desempenho das empilhadeiras, ou ainda a rapidez na montagem das estruturas para acelerar a inauguração e utilização das lojas (Figura 5).

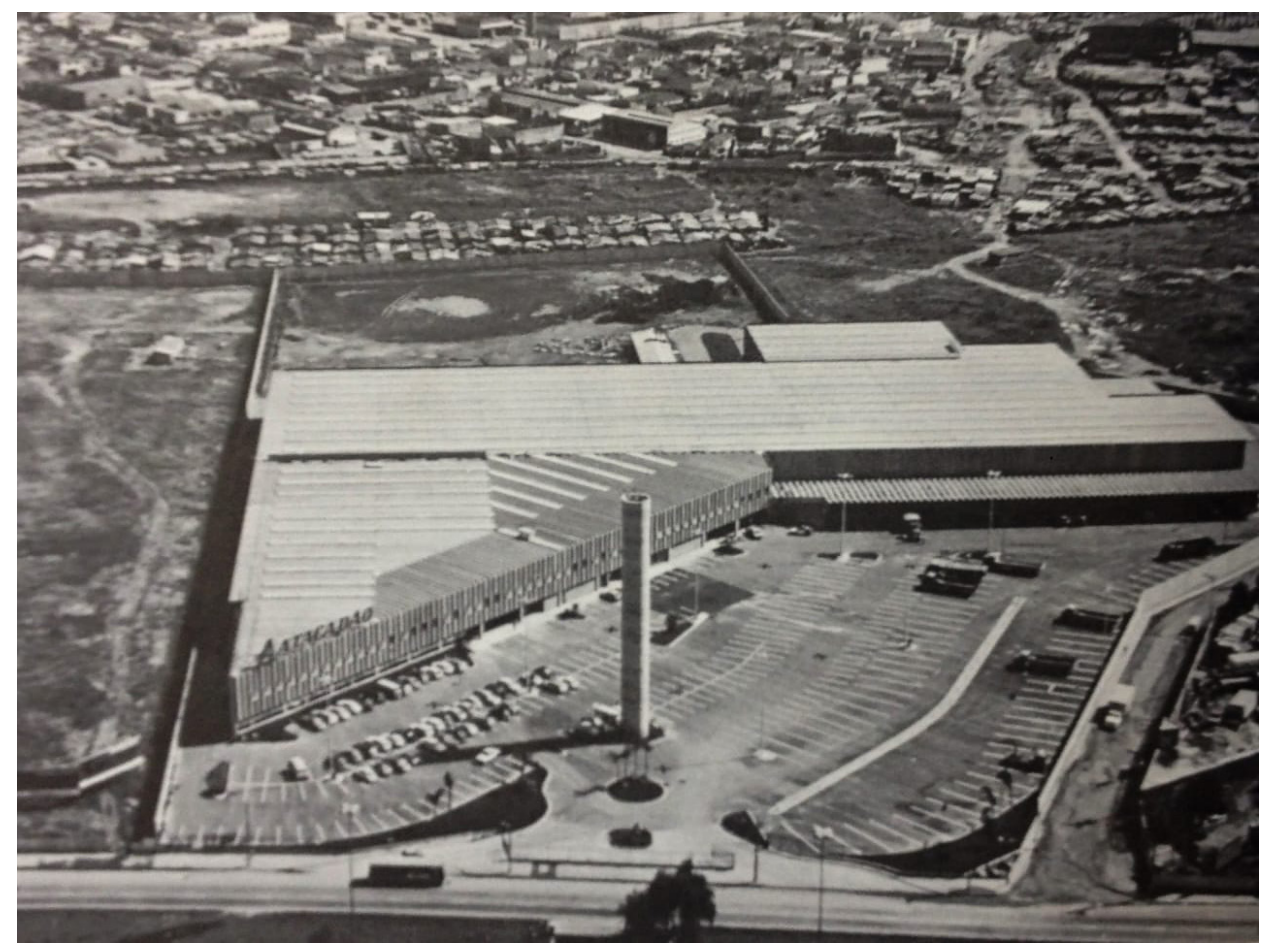


18 Entrevista com os autores em 27 jul. 2018

19 "Dados da Fundação Instituto de Pesquisas Econômicas (Fipe) mostram que entre 1980 e 1989 , a inflação média no país foi de $233,5 \%$ ao ano. Na década seguinte, entre os anos de 1990 e 1999, a variação anual subiu para 499,2\%." (G1, 2018, online)
O "lucro cessante - afirma Maitrejean (informação oral) ${ }^{18}$ - passou a ser uma variável arquitetônica, pois quanto antes a loja estivesse em funcionamento melhor seria o rendimento do lojista". Assim, projetos rápidos, com uma concepção de obra também rápida, passaram a ser o dia a dia do trabalho do escritório. Incluir métodos de montagem em seco, como o das estéreo-estruturas (com módulo fixo de 2,5 $\mathrm{x}$ 2,5m), desenvolvidas para o Atacadão, foi uma das estratégias de industrialização aprimorados pelo escritório Maitrejean \& Sallouti durante os anos 1980.

A produção dos tubos das estéreo-estruturas não dependia de um projeto específico, pelo contrário, eram fabricados de forma a poder atender mais de uma loja, estivesse ou não programada para ser construída num momento específico. Para Maitrejean, a relação direta entre o dono da loja, que era também o construtor, e seus fornecedores facilitava a programação e sistematização dos processos construtivos cíclicos. A forma de projetar também se modificou. Deixou de existir o edifício final único, passou a funcionar o sistema de construção de contentores, que dependia da formulação do programa e não das propostas plásticas específicas para cada caso. Assim, um número limitado e preciso de desenhos passou a ser suficientes para estabelecer os parâmetros das obras, não só a determinação dos aspectos físicos, mas fundamentalmente os cronogramas de execução e as tabelas de custos. O sistema industrializado facilitava o processo de projeto da mesma forma que facilitava a construção.

Outro fator importante para o sucesso do sistema de armazenamento foi de ordem económica. Durante os anos da hiperinflação, décadas de 1980 e 1990, ${ }^{19}$ a relação com as mercadorias mudou drasticamente. A combinação do fim do Milagre Econômico Brasileiro com a crise do petróleo (1973), "dívida externa elevada, indústria defasada [...] desvalorizações da moeda, para manter o Brasil competitivo (com uma maxidesvalorização em 1979); e pelo aumento do dinheiro em circulação para financiar a dívida externa" (G1, 2018, online), gerou novas estratégias empresariais em função da mudança rápida no preço dos produtos. Na hiperinflação o depósito de mercadorias passou a ser importante, não pela relação evidente com o abastecimento das lojas, mas como elemento de investimento. Produtos estocados em grandes armazéns, passaram a ser ativos importantes para o crescimento financeiro dos grupos que gerenciam redes varejistas como o Atacadão.

A experiência acumulada na confecção de projetos comerciais deu grande prestígio ao escritório que recebeu encomendas vindas da África, Angola (1986), onde o escritório realizou cinco propostas de hipermercados que não foram de fato construídos (Figura 6); do Uruguai, solicitado por um empresário local dono da Tienda Inglesa (1987), ou ainda, para Colômbia, também com supermercados. Fora os mais de 120 projetos realizados durante os anos de 1975 e 1987 e outros 80 mais, pelo menos, entre 1988 e 2013, que como dito foi o último ano de atividade projetiva de Jon Maitrejean. 


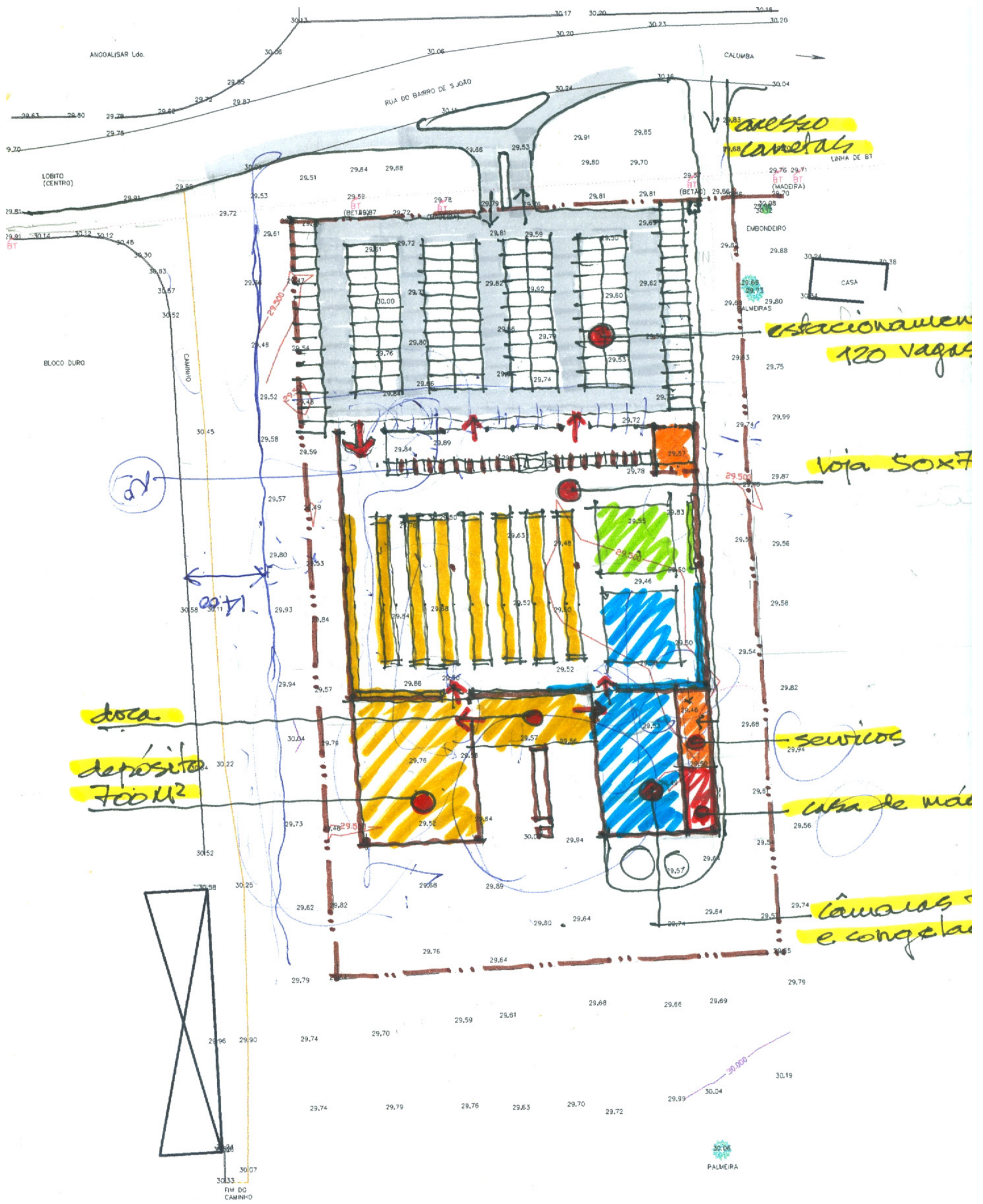

Figura 6: Estudo Hipermercado em Angola. Maitrejean \& Sallouti Associados Arquitetos, 1986. Fonte: Acervo do arquiteto Jon Maitrejean, cordialmente cedida. 
Figura 7: Jon Maitrejean na sua casa em São Paulo, 2018. Fonte: Fotografia de Paulo Fujioka.

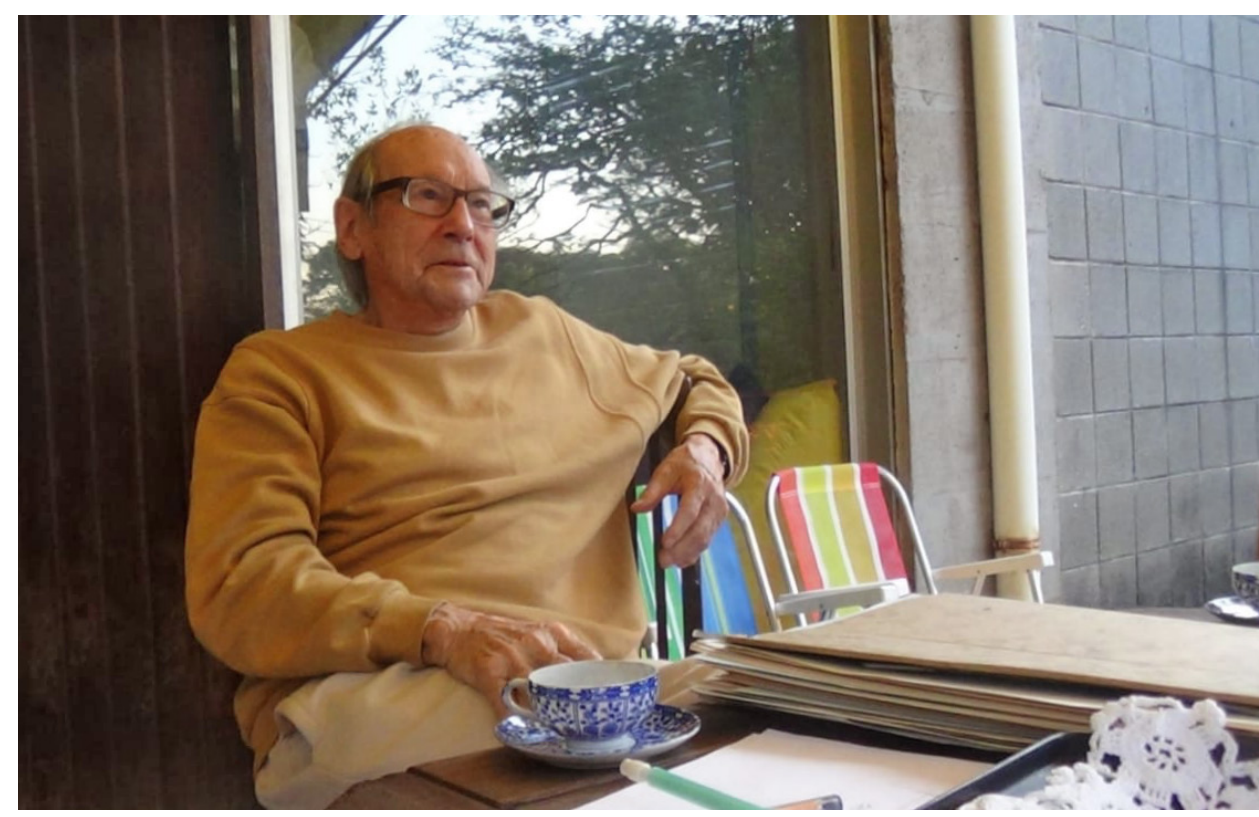

\section{Referências bibliográficas}

ASSOCIAÇÃO DOS DOCENTES DA USP. O controle ideológico na USP (1964-1978). São Paulo: Adusp, 2004. Disponível em: <https://www.adusp.org.br/files/cadernos/livronegro.pdf>. Acesso em: 10 jul. 2018.

BELLEZA, Gilberto Silva Domingues de Oliveira. Metodologia na apresentação de projetos de cinco arquitetos. 1997. Dissertação (mestrado em arquitetura e urbanismo) - Faculdade de Arquitetura e Urbanismo, Universidade de São Paulo, São Paulo.

CAMARGO, Beatriz Correa. A universidade de São Paulo durante o regime autoritário. Comissão da Verdade USP. Ficha individual. Jon Andoni Vergareche Maitrejean. 2015. Disponível em: $<$ http://sites.usp.br/comissaodaverdade/wp-content/uploads/sites/59/2015/07/Jon-Andoni-Vergareche-Maitrejean1.pdf>. Acesso em: 10 jul. 2018.

CAMARGO, Mônica Junqueira de. Inventário dos bens culturais relativos ao Plano de Ação do Governo Carvalho Pinto (1959-1963). Revista do CPC, São Paulo, n. 21, p.164-203, $1^{\circ}$ sem. 2016.

CRISPIN, Felipe Bueno. Entre a geografia e o patrimônio: estudo das ações de preservação das paisagens paulistas pelo Condephaat (1969-1989). 2014. Dissertação (Mestrado em História e Historiografia) - Escola de Filosofia, Letras e Ciências Humanas, Universidade Federal de São Paulo, Guarulhos.

ESTADO DE SÃO PAULO. Governo do Estado de São Paulo. Secretária de Estado da Cultura. Condephaat. Sessão Ordinária 1605ª. 29 nov. 2010. Ata. Disponível em: <https://raquelrolnik.files.wordpress.com/2010/12/condephaat-resolucao-tombamento-pacaembu-jardins. pdf $>$. Acesso em: 10 jun. 2018.

FERRO, Sergio. A FAU-USP e a Ditadura Militar. In: AMORIM, Paulo Henrique. Conversa Afiada. O silêncio faz da USP uma aliada da ditadura. Texto de Sérgio Ferro. 23 jun. 2015. Disponível em: <https://www.conversaafiada.com.br/brasil/2015/06/23/o-silencio-faz-da-usp-uma-aliada-da-ditadura>. Acesso em: 10 jul. 2018. 
FIALHO, Valéria Cássia dos Santos. Arquitetura, texto e imagem: a retórica da representação nos concursos de arquitetura. 2007. Tese (Doutorado em Projeto de Arquitetura) - Faculdade de Arquitetura e Urbanismo, Universidade de São Paulo, São Paulo.

G1. Economia. Como o Brasil chegou na hiperinflação? 2018. G1. Disponível em: <http:// g1.globo.com/economia/inflacao-como-os-governos-controlam/platb/category/sem-categoria/>. Acesso em 10 jul. 2018.

GRECO, Heloisa Amélia. Dimensões fundacionais da luta pela anistia. 2003. Tese (Doutorado em História) - Faculdades de Filosofia e Ciências Humanas, Universidade Federal de Minas Gerais, Belo Horizonte.

IAB. Instituto dos Arquitetos do Brasil. Departamento de São Paulo. Diretoria. 2018. Disponível em: <http://www.iabsp.org.br/iab-sao-paulo/diretoria/>. Acesso em: 10 jul. 2018.

JUNQUEIRA, Luiz Eduardo Vasconcellos. Os anexos da FAU-USP: do ateliê da Vila Penteado ao concurso de 1989. 2016. Dissertação (Mestrado em Projeto de Arquitetura) - Faculdade de Arquitetura e Urbanismo, Universidade de São Paulo, São Paulo.

JUSBRASIL. Página 52 da Executivo - Caderno 1 do Diário Oficial do Estado de São Paulo (DOSP). 4 jun. 2013. Disponível em: <https://www.jusbrasil.com.br/diarios/55080550/ dosp-executivo-caderno-1-04-06-2013-pg-52>. Acesso em: 10 jun. 2018.

MAITREJEAN, Jon. Atividade política e exílio. Depoimento sobre João Batista Vilanova Artigas. Vídeo. ARTIGAS, Laura; GORSKI, Pedro (Dirs.). Ocupação Vilanova Artigas: Atividade política e exílio. 2015. Disponível em: <https://www.youtube.com/watch?v=9-LOglKAi5U>. Acesso em: 10 jul. 2018.

MANTEGA, Guido. A Economia Política Brasileira. Rio de Janeiro: Polis / Vozes, 4 ed., 1986.

MATERA, Sérgio. Carlos Millan, um estudo sobre a produção em arquitetura. 2005. Dissertação (Mestrado em História e Fundamentos da Arquitetura e Urbanismo) - Faculdade de Arquitetura e Urbanismo, Universidade de São Paulo, São Paulo.

MILLAN, Carlos B. O Ateliê na Formação do Arquiteto. São Paulo: FAUUSP, 1962.

NOBRE, Ana Luiza. Ulm-Rio: questões de projeto. In: ENCONTRO NACIONAL DA ASSOCIAÇÃO NACIONAL DE PESQUISA E PÓS-GRADUAÇÃO EM ARQUITETURA E URBANISMO (ENANPARQ). 1. 2010, Rio de Janeiro, Simpósio Temático. Industrialização e planejamento: a produção e a distribuição social da arquitetura contemporânea. Rio de Janeiro: Enanparq, 2010, p. 1-20. Disponível em: <https://www.anparq.org.br/dvd-enanparq/simposios/67/67274-1-SP.pdf>. Acesso em: 10 jul. 2018.

RANIERI, Nina Beatriz Stocco (Org.). Autonomia Universitária na USP. 1934-1969. Vol. 1. São Paulo: Edusp, 2005.

RIBEIRO, Rogério; RIBEIRO, Ana Isabel; ROSENDO, Catarina. Vilanova Artigas Arquiteto: A cidade é uma casa. A casa é uma cidade. Almada, Portugal: Casa da Cerca, 2001.

SAFLEX. Maitrejean, influindo em seu tempo. Saflex na Arquitetura. São Paulo, ano 2, n. 11, monográfico, out/nov. 1988.

VIDOTTO, Taiana Car. A indissociável relação entre o ensino e a profissão na constituição do arquiteto e urbanista moderno no estado de São Paulo: 1978-1962. 2014. Dissertação (Mestrado em Arquitetura, Tecnologia e Cidade) - Faculdade de Engenharia Civil, Arquitetura e Urbanismo, Universidade Estadual de Campinas, Campinas.

VIDOTTO, Taiana Car; MONTEIRO, Ana Maria Reis de Goes. O discurso profissional e o ensino na formação do arquiteto e urbanista em São Paulo: 1948-1962. Pós, São Paulo, v. 22, n. 38, p. 20-37, dez. 2015. 
Textos do arquiteto:

MAITREJEAN, Jon. Sem (essa) estética. Arquitetura e Urbanismo(AU), São Paulo, n. 7, p.44-45, jun./jul. 1986.

RIBEIRO, Demétrio; GRAEFF, Edgard A.; MAITREJEAN, Jon. Análise de cursos de graduação. Projeto, São Paulo, n.81, p. 66-67, nov. 1985.

Outros livros, trabalhos acadêmicos e revistas onde aparecem obras do arquiteto:

A CONSTRUÇÃO. Holiday Inn Crown Plaza, São Paulo. Projeto de Maitrejean \& Sallouti Associados Arquitetos. A Construção em São Paulo, São Paulo, n. 1904, p. 18, 6 ago. 1984

Na zona sul, comércio de rua com segurança de shopping center; projeto de Maitrejean \& Sallouti Arquitetos Associados. A Construção em São Paulo, São Paulo, ano 25, n. 1819, p. 14-18, 20 dez. 1982.

Residência do arquiteto Jon Vergareche Maitrejean (1971). A Construção em São Paulo, ano 25, n. 1811, p. 24, 25 out. 1982.

A arquitetura e as obras do hipermercado Pães Mendonça; projeto de Maitrejean \& Sallouti Associados Arquitetos. A Construção em São Paulo, São Paulo, ano 24, n. 1734, p. 8-17, 4 mai. 1981.

ACAYABA, Marlene M. Residências em São Paulo: 1947-1975. São Paulo: Projeto, 1986.

ACROPOLE. Residência em Interlagos. Projeto Jon Maitrejean. Acropole, São Paulo, ano 29, n. 348, p.34-35, 1968. [casa para investimento]

Residência em Interlagos. Projeto Jon V. Maitrejean. Acropole, São Paulo, ano 29, n. 345, p.34-37, nov. 1967. [Residência Feliciano Freire Mata]

Residência no Pacaembu. Projeto Jon V. Maitrejean. Acropole, São Paulo, ano 28, n. 337, p.34-35, mar. 1967. [Residência José Mutarelli]

Residência no Brooklin. Projeto Jon Maitrejean; Tomoshigue Kusuno, paisagista. Acropole, São Paulo, ano 28, n. 331, p.19-21, ago. 1966. [Residência Raimar Richter]

Residência na Chácara Flora. Jon Maitrejean, arquiteto; Daisy Igel e Helmut Hein, colaboradores. Acropole, São Paulo, ano 24, n. 285, p.286-287, ago. 1962.

Anteprojeto para a Assembleia Legislativa de Minas Gerais (a). Projeto: Francisco Petracco, Jon V. Maitrejean, Nelson Morse e Telesforo Cristofani. Acropole, São Paulo, ano 24, n. 283, p.217-221, jun. 1962.

Projeto para a Assembleia Legislativa de São Paulo. Projeto classificado em $4^{\circ}$ lugar. Arquiteto: Jon V. Maitrejean. Acropole, São Paulo, ano 23, n. 274, p.351-353, set. 1961.

Residência no Jardim Europa. Jon Maitrejean, arquiteto; Daisy Igel e Helmut Hein, colaboradores. Acropole, São Paulo, ano 22, n. 260, p.198-201, mai. 1960. [Residência Pedro Franco Piva]

Interior de um apartamento. Projeto: Jon Maitrejean, Daisy Igel, Helmut Offenberg. Acropole, São Paulo, ano 21, n. 244, p.152-153, fev. 1959.

Anteprojeto da terminal Cia. Ultragaz - São Paulo. Projeto: Daisy R. Igel - Jon Maitrejean. Acropole, São Paulo, ano 18, n. 205, p.21-23, jun. 1955.

ARQUITETURA DO BRASIL. Estádio Serra Dourada, Goiânia, GO. Jon Vergareche Maitrejean e equipe (Georges Sallouti, Dicran Kassardjian, José Alberto Soares e Helena Afanasieff, arqs.). Arquitetura do Brasil (AB), n. 13, p. 22-31, 1981. 
MÓDULO. Estádio Municipal Serra Dourada, Goiânia, GO (1973). Projeto de: Paulo A. Mendes da Rocha e Roberto Portugal Albuquerque; detalhamento: Jon Maitrejean e Georges Sallouti. Módulo, Rio de Janeiro, n. 86, p. 83-85, jul. 1985.

PROJETO. Hipermercado Paes Mendonça (Belo Horizonte, MG). Projeto de Maitrejean \& Sallouti. Projeto, São Paulo, n. 145, p. 74-75, set. 1991.

Supermercado Sé (São Paulo, SP). Projeto de Jon Maitrejean e Georges Sallouti. Projeto, São Paulo, n. 132, p. 43, jun. 1990.

Em São Paulo, um Hipermercado de 48.000 m2 de área construída. Projeto de Maitrejean \& Sallouti Associados Arquitetos. Suplemento Projeto / Guia Projeto, São Paulo, n. 104, p. 18-19, out. 1987. (Suplemento à Projeto, 104).

Soluções modernas em armazém atacadista. Projeto de Maitrejean \& Sallouti Associados Arquitetos. Projeto, São Paulo, n. 80, p. 84-85, out. 1985.

Simplicidade e funcionalidade da organização até as fachadas. Supermercados Sé, São Paulo. Projeto de Jon Maitrejean e Georges Sallouti. Projeto, São Paulo, n. 70, p. 6265, dez. 1984.

XAVIER, Alberto; LEMOS, Carlos; CORONA, Eduardo. Arquitetura Paulistana. São Paulo: Pini, 1983.

WEINTRAUB. Alan; HESS, Alan; LEFÈVRE, José Eduardo de Assis. Casa Modernista: A History of the Brazil Modern House. New York, Rizzoli, 2010. 